\title{
EFFECT OF PROCESS PARAMETERS FOR OPTIMUM MATERIAL REMOVAL RATE OF CYLINDRICAL GRINDING OF AISI 1045 STEEL
}

\author{
Taranveer Singh, Khushdeep Goyal ${ }^{*}$, Parlad Kumar \\ Department of Mechanical Engineering, Punjabi University, Patiala-147002, India \\ *Corresponding e-mail: khushgoyal@yahoo.com
}

\begin{abstract}
In this experimental work, the effect of various input parameters viz. work speed, wheel speed, abrasive material, depth of cut, concentration of cutting fluid and number of passes has been studied on the material removal rate of cylindrical grinded AISI. For experimentation, three levels of each variable have been selected except wheel speed. Two levels of wheel speed have been taken. Heat treated AISI 1045 has been considered as work piece material. The result reveals that number of passes followed by the type of abrasive material is the most significant to influence material removal rate. The optimum set of input parameters for maximizing the material removal rate has also been found.
\end{abstract}

Keywords: Input parameters, grinding, material removal rate, abrasive material

\section{INTRODUCTION}

The cylindrical grinding is a manufacturing process whose complex characteristic determine the technological output and quality of a product. The material removal rate is one of most critical quality constraint for selection of grinding factors in process planning. In the present study AISI 1045 steel has been selected as the test material because it is an important material used for making axles, bolts, connecting rods, pins spindles, crank shaft, guide rods etc. Agarwal et al. ${ }^{1}$ developed an analytical model for surface roughness prediction of ground ceramics based on the analysis of grooves left by the grains that interact with the work piece which is characterized by the under formed chip thickness. The authors observed that at higher speed ratio, the surface finish is better. Also the surface roughness increased with an increase in depth of cut and feed. Shih et al. ${ }^{2}$ conducted the experiment to investigate the effect of wheel speed, coolant flow rate and truing on Zirconia and M2 tool steel using a vitreous bond CBN wheel for high speed grinding. The author found that both normal and tangential grinding forces were reduced, but material removal rate and roundness of ground parts did not improve. High coolant flow rate eliminate grinding burn on M2 steel layer and layer of Zirconia powder on wheel after grinding Zirconia. Marsh et al. ${ }^{3}$ studied the grinding force and work piece form error during cylindrical plunge grinding. In experiment two spindle arrangements with four capacitive probes embedded in work spindle which give grinding force by measuring the time varying gap between spindle rotor and stator was used.

Nathan et al. ${ }^{4}$ studied on In-process monitoring of grinding burn in the cylindrical grinding of steel. In steels burn is characterized by a visible bluish temper colour on the ground surface. The authors found that spark temperature can be considered to be good representative of grinding zone temperature and hence useful for process-monitoring purposes. Kumar et al. $^{5}$ conducted experiments to optimize material removal and process parameters of cylindrical grinding with the help of Taguchi Method. The variables selected were depth of cut and cutting speed with three levels selected for both of the variables. From experiments the authors concluded, the optimal grinding conditions for MRR these were: Cutting Speed: $41.07 \mathrm{~m} / \mathrm{min}$ and depth of cut: $0.020 \mathrm{~mm}$. The optimal material removal rate was $19.906 \mathrm{~mm}^{3} / \mathrm{sec}$. Sahin $^{6}$ studied wear resistance of three types of steels a low carbon steel (A1SI 1020), Carbon steel (A1SI 1340) and low alloyed steel (A1SI 5150) on a pinon-disc type apparatus. The experiments were carried to analyze the influence of testing parameters on weight loss of various steel work pieces. An L9 orthogonal array was used. The orthogonal array, signal-to-noise ratio and analysis of variance were used to investigate the optimal testing Parameters. For AISI 1340 steel, abrasive grain size exerted the most or greatest effect on wear, but in AISI 1020 and AISI 5150 steels sliding distance exerted greatest effect on the weight loss. George et al. ${ }^{7}$ taken random distribution of the grain protrusion heights into account and simulation shows that the root part of surface is smoother than the top part and these results are consistent with experiment. Janardhan et $a^{8}{ }^{8}$ proposed that in cylindrical grinding surface finish is the important response and tried to predict the grinding behavior and to achieve optimal operating process parameters. From Pareto analysis, the authors found that feed rate played most important role on surface roughness. Singh et al. ${ }^{10}$ measured the performance in terms of optimization of material removal rate. After performing the experiment, results of both wires have been compared. It is found that the cryogenically treated zinc coated diffused brass wire gives good material removal rate as compare to cryogenically treated plain brass wire.

On the basis of the literature following objectives of this experimentation are to determine the effect of input parameters on material removal rate and to 
determine optimum set of input parameters for better surface finish.

\section{EXPERIMENTAL DESIGN}

In the present research work, AISI 1045 steel was selected as the work piece material, which is a medium carbon steel. This material offers a very good balance of strength and ductility. Due to these properties it is generally used for making shafts and gears. AISI 1045 steel is also used in manufacturing of axles, machine parts, studs, pinions and pins. Three types of grinding wheels used in this experimentation were: White aluminum oxide, Green silicon carbide and Black aluminum oxide. Table 1 shows L18 array with different input parameters and their respective levels.

Table 1. L18 Experimental Design.

\begin{tabular}{|c|c|c|c|c|c|c|}
\hline Des. & $\mathbf{A}$ & B & $\mathbf{C}$ & D & $\mathbf{E}$ & $\mathbf{F}$ \\
\hline $\begin{array}{l}\text { Exp. } \\
\text { No. }\end{array}$ & $\begin{array}{c}\text { Wheel } \\
\text { speed(rpm) }\end{array}$ & $\begin{array}{l}\text { Work piece } \\
\text { speed(rpm) }\end{array}$ & $\begin{array}{l}\text { Abrasive } \\
\text { material }\end{array}$ & $\begin{array}{l}\text { Depth of } \\
\text { cut }(\mu \mathrm{m})\end{array}$ & $\begin{array}{l}\text { Conc. of cutting } \\
\text { fluid }(\%)\end{array}$ & $\begin{array}{c}\text { Number of } \\
\text { passes }\end{array}$ \\
\hline 1 & 2100 & 250 & A 60B & 15 & 3 & 2 \\
\hline 2 & 2100 & 250 & A $60 \mathrm{~W}$ & 20 & 4 & 3 \\
\hline 3 & 2100 & 250 & SIC 60G & 25 & 5 & 4 \\
\hline 4 & 2100 & 500 & A 60B & 15 & 4 & 3 \\
\hline 5 & 2100 & 500 & A $60 \mathrm{~W}$ & 20 & 5 & 4 \\
\hline 6 & 2100 & 500 & SIC 60G & 25 & 3 & 2 \\
\hline 7 & 2100 & 710 & A $60 \mathrm{~B}$ & 20 & 3 & 4 \\
\hline 8 & 2100 & 710 & A $60 \mathrm{~W}$ & 25 & 4 & 2 \\
\hline 9 & 2100 & 710 & SIC 60G & 15 & 5 & 3 \\
\hline 10 & 2640 & 250 & A 60B & 25 & 5 & 3 \\
\hline 11 & 2640 & 250 & A $60 \mathrm{~W}$ & 15 & 3 & 4 \\
\hline 12 & 2640 & 250 & SIC 60G & 20 & 4 & 2 \\
\hline 13 & 2640 & 500 & A 60B & 20 & 5 & 2 \\
\hline 14 & 2640 & 500 & A $60 W$ & 25 & 3 & 3 \\
\hline 15 & 2640 & 500 & SIC 60G & 15 & 4 & 4 \\
\hline 16 & 2640 & 710 & A $60 \mathrm{~B}$ & 25 & 4 & 4 \\
\hline 17 & 2640 & 710 & A $60 \mathrm{~W}$ & 15 & 5 & 2 \\
\hline 18 & 2640 & 710 & SIC 60G & 20 & 3 & 3 \\
\hline
\end{tabular}

Legends: A 60B = Aluminum 60 (black), A 60W= Aluminum 60 (white), SIC 60G= Silicon carbide 60 (green)

\section{EXPERIMENTAL RESULTS}

The Table 2 shows material removal rate as well as values of $\mathrm{S} / \mathrm{N}$ ratio for material removal rate for all treatments. The initial diameter of each work piece was taken as $29.3 \mathrm{~mm}$ after rough turning. Three cuts with grinding wheel were applied on each work piece. Out of three, two were rough cuts of 50 micron each and third was finish cut. In case of material removal rate, the principle of higher is better option has been followed for calculation of $\mathrm{S} / \mathrm{N}$ ratio.

Results obtained from the experiments were analyzed using ANOVA, as shown in Table 3, which helps in predicting the significance of input parameters taken for any desired response function.

At $5 \%$ level of significance $F_{0.05,2,11}=3.98$, with pooled error variance, number of passes shows significant effect. The effect of grinding wheel speed, concentration of cutting fluid and depth of cut are not significant parameters.
In the last row of Table 4 ranks have been given to various factors according to delta value. Higher is the rank, higher is the significance. The number of passes has the highest (rank 1) and is the most significant factor followed by abrasive material (rank 2) and work speed with (rank 3). The wheel speed with its lowest rank is least significant in affecting the material removal rate.

\section{RESULTS AND DISCUSSION}

Main effect plots and interaction for material removal rate are shown in Figs. 1 to 6 . Main effect plot shows the variation of material removal rate with each of variable i.e. wheel speed, work speed, abrasive material, depth of cut, concentration of cutting fluid and number of passes. In each plot Xaxis represents the change in level of variable and $\mathrm{Y}$ axis represents the $\mathrm{S} / \mathrm{N}$ ratio of the level or represents the change in resultant response. 
Table 2. S/N ratios for material removal rate.

\begin{tabular}{|c|c|c|c|c|c|c|c|c|}
\hline Exp. & $\begin{array}{l}\text { Wheel } \\
\text { speed } \\
\text { (rpm) }\end{array}$ & $\begin{array}{l}\text { Work } \\
\text { piece } \\
\text { speed } \\
(\text { rpm) }\end{array}$ & $\begin{array}{l}\text { Abrasive } \\
\text { material }\end{array}$ & $\begin{array}{c}\text { Depth } \\
\text { of cut } \\
(\mu \mathrm{m})\end{array}$ & $\begin{array}{c}\text { Conc. of } \\
\text { cutting } \\
\text { fluid } \\
(\%)\end{array}$ & $\begin{array}{l}\text { Number } \\
\text { of passes }\end{array}$ & $\begin{array}{c}\text { Material } \\
\text { removal } \\
\text { rate } \\
(\mathrm{g} / \mathrm{min})\end{array}$ & $\begin{array}{c}\mathrm{S} / \mathrm{N} \\
\text { ratio } \\
(\mathrm{dB})\end{array}$ \\
\hline 1 & 2100 & 250 & A 60B & 15 & 3 & 2 & 4.94 & 13.874 \\
\hline 2 & 2100 & 250 & A $60 \mathrm{~W}$ & 20 & 4 & 3 & 4.17 & 12.402 \\
\hline 3 & 2100 & 250 & SIC 60G & 25 & 5 & 4 & 3.93 & 11.888 \\
\hline 4 & 2100 & 500 & A 60B & 15 & 4 & 3 & 4.14 & 12.340 \\
\hline 5 & 2100 & & A $60 \mathrm{~W}$ & 20 & 5 & 4 & 2.56 & 8.164 \\
\hline 6 & 2100 & 500 & SIC 60G & 25 & 3 & 2 & 3.39 & 10.603 \\
\hline 7 & 2100 & 710 & A 60B & 20 & 3 & 4 & 3.31 & 10.396 \\
\hline 8 & 2100 & 710 & A $60 W$ & 25 & 4 & 2 & 3.59 & 11.101 \\
\hline 9 & 2100 & 710 & SIC 60G & 15 & 5 & 3 & 3.20 & 10.102 \\
\hline 10 & 2640 & 250 & A 60B & 25 & 5 & 3 & 3.86 & 11.731 \\
\hline 11 & 2640 & 250 & A $60 \mathrm{~W}$ & 15 & 3 & 4 & 2.79 & 8.912 \\
\hline 12 & 2640 & 250 & SIC 60G & 20 & 4 & 2 & 4.07 & 12.191 \\
\hline 13 & 2640 & 500 & A 60B & 20 & 5 & 2 & 4.74 & 13.515 \\
\hline 14 & 2640 & 500 & A $60 \mathrm{~W}$ & 25 & 3 & 3 & 3.80 & 11.595 \\
\hline 15 & 2640 & 500 & SIC 60G & 15 & 4 & 4 & 2.15 & 6.648 \\
\hline 16 & 2640 & 710 & A $60 \mathrm{~B}$ & 25 & 4 & 4 & 3.74 & 11.457 \\
\hline 17 & 2640 & 710 & A $60 \mathrm{~W}$ & 15 & 5 & 2 & 5.46 & 14.743 \\
\hline 18 & 2640 & 710 & SIC 60G & 20 & 3 & 3 & 3.43 & 10.705 \\
\hline
\end{tabular}

Legends: A 60B= Aluminum 60 (black), A 60W= Aluminum 60 (white), SIC 60G= Silicon carbide 60 (green).

Table 3. ANOVA for $\mathrm{S} / \mathrm{N}$ ratio for material removal rate $(\mathrm{Ra})$.

\begin{tabular}{|l|c|c|c|c|c|c|}
\hline \multicolumn{1}{|c|}{ Source } & $\begin{array}{c}\text { Sum of } \\
\text { square }\end{array}$ & $\begin{array}{c}\text { Degree of } \\
\text { freedom }\end{array}$ & $\begin{array}{c}\text { Mean } \\
\text { square }\end{array}$ & F-value & Status & $\begin{array}{c}\text { Percentage } \\
\text { contribution }\end{array}$ \\
\hline Work-piece speed & 5.787 & 2 & 2.893 & 1.44 & Not significant & $4.38 \%$ \\
\hline Abrasive material & 10.481 & 2 & 5.240 & 2.63 & Not Significant & $7.93 \%$ \\
\hline Number of passes & 29.215 & 2 & 14.607 & 7.347 & Significant & $22.11 \%$ \\
\hline Residual error & 21.878 & 11 & 1.988 & & & $16.55 \%$ \\
\hline Total & 132.120 & 17 & & & & \\
\hline
\end{tabular}

Table 4. Response table for mean signal-to-noise ratio for material removal rate.

\begin{tabular}{|c|l|l|l|l|l|l|}
\hline & A & B & C & D & E & F \\
\hline Level & $\begin{array}{l}\text { Wheel } \\
\text { speed } \\
(\mathbf{r p m})\end{array}$ & $\begin{array}{l}\text { Work } \\
\text { speed } \\
(\mathbf{r p m})\end{array}$ & $\begin{array}{l}\text { Abrasive } \\
\text { material }\end{array}$ & $\begin{array}{l}\text { Depth of } \\
\text { cut } \\
(\boldsymbol{\mu m})\end{array}$ & $\begin{array}{l}\text { Conc. } \\
\text { cutting fluid } \\
(\boldsymbol{\%})\end{array}$ & $\begin{array}{l}\text { Number of } \\
\text { passes }\end{array}$ \\
\hline $\mathbf{1}$ & 11.207 & $11.833^{*}$ & $12.218^{*}$ & 11.103 & 11.014 & $12.671^{*}$ \\
\hline $\mathbf{2}$ & $11.277^{*}$ & 10.477 & 11.152 & 11.228 & 11.023 & 11.479 \\
\hline $\mathbf{3}$ & -------- & 11.417 & 10.356 & $11.395^{*}$ & $11.690^{*}$ & 9.577 \\
\hline DELTA & 0.070 & 1.356 & 1.862 & 0.292 & 0.667 & 3.094 \\
\hline RANK & \multicolumn{7}{|c|}{6} & 3 & 2 & 5 & 4 & 1 \\
\hline
\end{tabular}

Journal of Mechanical Engineering, Vol. ME 44, No. 2, December 2014 Transaction of the Mechanical Engineering Division, The Institution of Engineers, Bangladesh 
Figure 1 shows that wheel speed does not have any effect on surface roughness; Plot for wheel speed shows almost a straight horizontal line, means that there is very less change in response with changing levels of wheel speed.

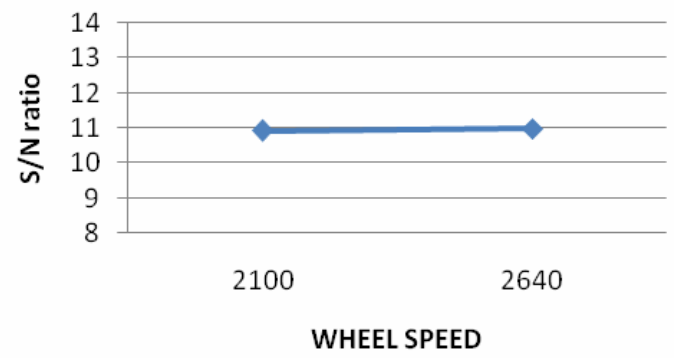

Figure 1. Main effect plot of means of $\mathrm{S} / \mathrm{N}$ ratios of MRR for grinding wheel speed.

Figure 2 shows that $\mathrm{S} / \mathrm{N}$ ratio decreases as speed is increased from $250 \mathrm{rpm}$ to $500 \mathrm{rpm}$ and it further increases as speed is changed to $710 \mathrm{rpm}$, this shows that $\mathrm{S} / \mathrm{N}$ ratio is maximum for work piece speed of $250 \mathrm{rpm}$ and at this value MRR is maximum. Similar results have been shown by Jagtap et al. ${ }^{9}$.

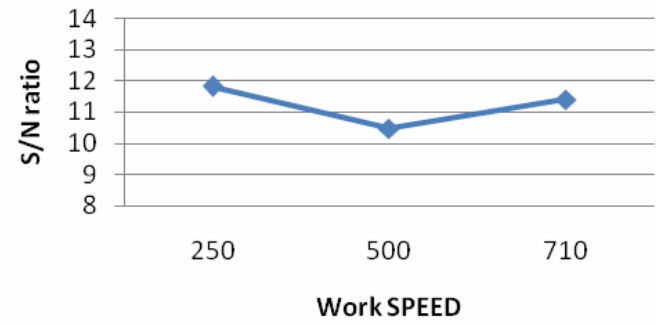

Figure 2. Main effect plot of means of $\mathrm{S} / \mathrm{N}$ ratios of MRR for work piece speed.

Figure 3 shows that $\mathrm{S} / \mathrm{N}$ ratio is maximum with aluminum 60 (black) abrasive material, therefore gives maximum value of MRR. Due to large variation in $\mathrm{S} / \mathrm{N}$ ratio, abrasive material is a significant factor.

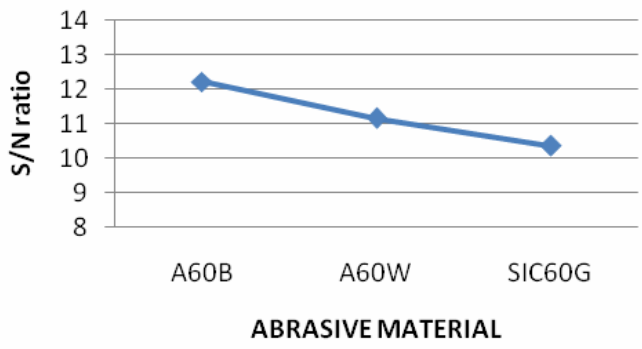

Figure 3. Main effect plot of means of $\mathrm{S} / \mathrm{N}$ ratios of MRR for abrasive wheel type.

From Fig. 4, it is observed that $\mathrm{S} / \mathrm{N}$ ratio is slightly increases when depth of cut increases from
$15 \mu \mathrm{m}$ to $20 \mu \mathrm{m}$ and then again increases when depth of cut increases from $20 \mu \mathrm{m}$ to $25 \mu \mathrm{m}$. As depth of cut increases, the material removal rate also increases. Similar results have been shown by Jagtap et al. ${ }^{9}$.

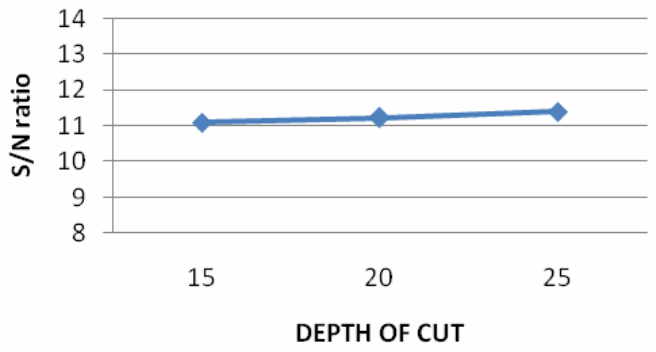

Figure 4. Main effect plot of means of $\mathrm{S} / \mathrm{N}$ ratios of MRR for depth of cut.

From Fig. 5 it can be observed that the change in $\mathrm{S} / \mathrm{N}$ ratio with change in concentration of cutting fluid is very small. The MRR increases with increase in concentration of cutting fluid. The maximum MRR was found at $5 \%$ concentration of cutting fluid.

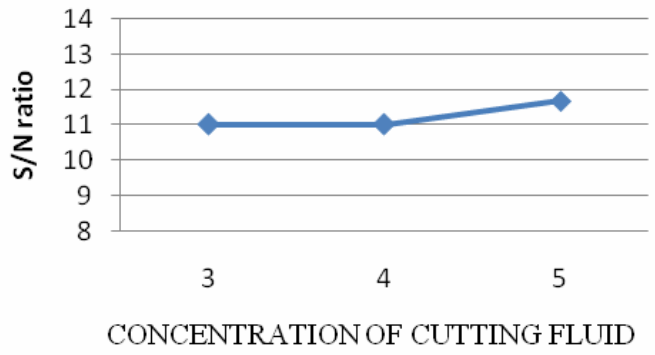

Figure 5. Main effect plot of means of $\mathrm{S} / \mathrm{N}$ ratios of MRR for concentration of cutting fluid.

The $\mathrm{S} / \mathrm{N}$ ratio plot for number of passes is given in Figure 6. The MRR is maximum with 2 number of passes and it decreases with increase in number of passes. It is due to the fact that at every pass the depth of cut remains unchanged and there is very less material removal rate in each pass. Jagtap et al. ${ }^{9}$ also shows that as the number of passes increases the $\mathrm{S} / \mathrm{N}$ ratio decreases.

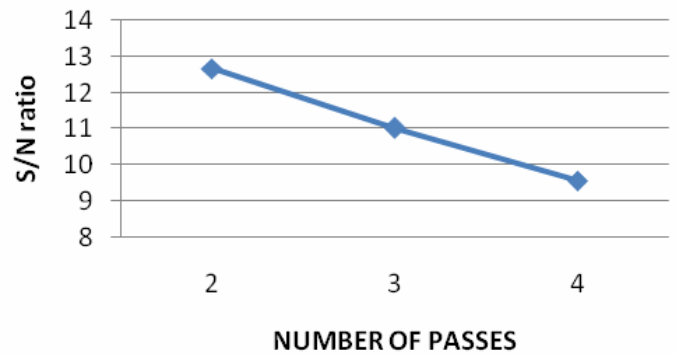

Figure 6. Main effect plot of means of $\mathrm{S} / \mathrm{N}$ ratios of MRR for number of passes.

Journal of Mechanical Engineering, Vol. ME 44, No. 2, December 2014

Transaction of the Mechanical Engineering Division, The Institution of Engineers, Bangladesh 
The optimum values of input parameters for material removal rate is found from the above discussion and are shown in Table 5.

Table 5. Optimal values of parameters for MRR.

\begin{tabular}{|l|c|c|}
\hline \multicolumn{1}{|c|}{$\begin{array}{c}\text { Input } \\
\text { parameters }\end{array}$} & $\begin{array}{c}\text { Optimum } \\
\text { set }\end{array}$ & $\begin{array}{c}\text { Optimum } \\
\text { value }\end{array}$ \\
\hline Wheel speed & A2 & $2640 \mathrm{rpm}$ \\
\hline Work speed & B1 & $250 \mathrm{rpm}$ \\
\hline Abrasive wheel & C1 & A 60 (black) \\
\hline Depth of cut & D 3 & $25 \mu \mathrm{m}$ \\
\hline $\begin{array}{l}\text { Concentration of } \\
\text { cutting fluid }\end{array}$ & E3 & $5 \%$ \\
\hline $\begin{array}{l}\text { Number of } \\
\text { passes }\end{array}$ & F1 & 2 \\
\hline
\end{tabular}

\section{CONCLUSIONS}

The effect of six independent variables was studied for the material removal rate (MRR) of AISI 1045 steel and following conclusions are found:

- Number of passes, abrasive material and work speed were three factors which mainly affect material removal rate.

- Number of passes was found to be most significant factor for material removal rate. The MRR decreases with increase in number of passes. Therefore for more MRR the number of passes should be minimum.

- The A 60B abrasive material (out of the tested three) gives the maximum MRR.

- The wheel speed, depth of cut and concentration of cutting fluid do not have significant effect on material removal rate.

- For optimal results of material removal rate the set of parameters is: high value of wheel speed of 2640 rpm, low work speed of $250 \mathrm{rpm}$, aluminum 60 (black) abrasive wheel, depth of cut $25 \mu \mathrm{m}$, concentration of cutting fluid $5 \%$ and number of passes 2 .

\section{REFERENCES}

1. Agarwal, S., Rao, P.V., 2010, "Modeling and Prediction of Surface Roughness in Ceramic Grinding”, Int. J. of Machine Tools and Manufacture, Vol. 50, pp.1065-76.

2. Shih, A.J., Grant, M.B., Yonushonis T.M., Morris, T.O., and McSpadden, S.B., 1998, "Vitreous Bond CBN Wheel for High Speed Grinding of Zirconia and M2 Tool Steel", Transactions of NAMRI/SME, Vol. 26, pp. 195-200.

3. Marsh, E.R., Moerlein, A.W., Deakyne, T.R.S., and Doren M.J.V., 2008, "In-process Measurement of Form Error and Force in Cylindrical-Plunge Grinding”, Precision Engineering, Vol. 32, pp. 34852.

4. Nathan, R.D., Vijayaraghavan, L., and Krishnamurthi, R, 1999, "In-process Monitoring of Grinding Burn in Cylindrical Grinding of Steel", J. of Material Processing Technology, Vol. 91, pp. 37-42.

5. Kumar, K., Chattopadhyaya, S., and Singh, H., 2012, "Optimal Material Removal and Effect of Process Parameters of Cylindrical Grinding Machine by Taguchi Method", Int. J. of Advanced Engineering Research and Studies, Vol. 2 (1), pp. 3943.

6. Sahin, Y., 2005, "Optimal Testing Parameters on the Wear Behaviour of Various Steels", Materials and Design, Vol. 27, pp. 455-60.

7. George, L.P., Job, K.V., and Chandran, I.M., 2013, "Study on Surface Roughness and its Prediction in Cylindrical Grinding Process based on Taguchi method of Optimization", Int. J. of Scientific and Research publications, Vol. 3 (5).

8. Janardhan, M., Krishna, A.G., 2011, "Determination and optimization of cylindrical grinding process parameters using Taguchi method and regression analysis", Int. J. of engineering science and Technology, Vol. 3(7), pp. 5659-65.

9. Jagtap, K.R., Ubale, S.B., and Kadam, M.S. 2011, "Optimization of Cylindrical Grinding Process Parameters for AISI 5120 Steel using Taguchi Method", Int. J. of Design and Manufacturing Technology, Vol. 2 (1), pp. 47-56.

10. Singh, N., Kumar, P., and Goyal, K., 2014, "Effect of Two Different Cryogenic Treated Wires in Wire Electrical Discharge Machining Of Aisi D3 Die Steel", J. of Mechanical Engineering, 43(2), pp. 5460 . 